\title{
Simiduia agarivorans gen. nov., sp. nov., a marine, agarolytic bacterium isolated from shallow coastal water from Keelung, Taiwan
}

Correspondence
Wung Yang Shieh
winyang@ntu.edu.tw

\author{
Wung Yang Shieh, ${ }^{1}$ Tung Yen Liu, ${ }^{1}$ Silk Yu Lin, ${ }^{1}$ Wen Dar Jean ${ }^{2}$ \\ and Jwo-Sheng Chen ${ }^{3}$
}

\author{
${ }^{1}$ Institute of Oceanography, National Taiwan University, PO Box 23-13, Taipei, Taiwan \\ ${ }^{2}$ Center for General Education, Leader University, No. 188, Sec. 5, An-Chung Rd, Tainan, Taiwan \\ ${ }^{3}$ College of Health Care, China Medical University, No. 91, Shyue-Shyh Rd, Taichung, Taiwan
}

\begin{abstract}
A Gram-negative, heterotrophic, agarolytic, marine bacterium, designated strain $\mathrm{SA} 1^{\top}$, was isolated from a seawater sample collected in the shallow coastal region of Keelung, Taiwan. Cells were straight to slightly curved rods. Nearly all of the cells were non-motile and non-flagellated during the exponential phase of growth in broth cultures; a few cells $(<1 \%)$ were motile and were considered to have monotrichous flagella. The isolate required $\mathrm{NaCl}$ for growth and grew optimally at $30-35{ }^{\circ} \mathrm{C}$ and $2-3 \%(\mathrm{w} / \mathrm{v}) \mathrm{NaCl}$. It grew aerobically and was incapable of anaerobic growth by fermentation of glucose or other carbohydrates. However, anaerobic growth could be achieved by reduction of nitrate to nitrite. Polar lipids comprised phosphatidylethanolamine (71.8\%), diphosphatidylglycerol (12.7\%), phosphatidylglycerol (12.2\%) and phosphatidylserine (3.3\%). Isoprenoid quinones consisted of Q-10 (87.5\%), MK-9 (6.6\%) and MK-7 (5.9\%).

Major cellular fatty acids were $\mathrm{C}_{16: 1} \omega 7 \mathrm{c}$ and/or iso- $\mathrm{C}_{15: 0} 2-\mathrm{OH}(28.6 \%), \mathrm{C}_{17: 1} \omega 8 \mathrm{c}(22.8 \%)$, $\mathrm{C}_{16: 0}(14.5 \%), \mathrm{C}_{18: 1} \omega 7 c(11.0 \%)$ and $\mathrm{C}_{17: 0}(6.4 \%)$. The DNA G+C content was $55.6 \mathrm{~mol} \%$. Phylogeny based on 16S rRNA gene sequence analysis showed that strain $\mathrm{SA}^{\top}{ }^{\top}$ formed a distinct lineage within the class Gammaproteobacteria. Strain $S A 1^{\top}$ was related most closely to Teredinibacter turnerae, Cellvibrio spp., Saccharophagus degradans, Pseudomonas spp. and Microbulbifer spp., strains of these species sharing <93\% 16S rRNA gene sequence similarity with strain $S A 1^{\top}$. The phylogenetic data and those from physiological, morphological and chemotaxonomic characterizations indicated that strain $S A 1^{\top}$ represents a novel species and genus, for which the name Simiduia agarivorans gen. nov., sp. nov. is proposed. The type strain is $\mathrm{SA} 1^{\top}\left(=\mathrm{BCRC} 17597^{\top}=\mathrm{JCM} 13881^{\top}\right)$.
\end{abstract}

Agar, a complex polysaccharide extracted from marine red algae, is employed widely as a gelling agent for microbiological culture media. Hydrolysis of this refractory material is a property found only among the domain Bacteria. Hydrolysis of agar is indicated by the development of depressions, softening or, in some cases, complete liquefaction of the agar surrounding colonies of agarolytic bacteria.

A novel agarolytic isolate, strain $\mathrm{SAl}^{\mathrm{T}}$, was recovered in our laboratory from a seawater sample collected in the shallow coastal region of Keelung, Taiwan, during a survey of the diversity of heterotrophic marine bacteria. Data from the

The GenBank/EMBL/DDBJ accession number for the 16S rRNA gene sequence of strain $\mathrm{SA} 1^{\top}$ is EF617350.

A maximum-likelihood tree showing the phylogenetic relationship between strain $\mathrm{SA} 1^{\top}$ and related bacteria in the class Gammaproteobacteria is available with the online version of this paper. present polyphasic study indicate that this isolate represents a novel species and genus.

A seawater sample collected from the shallow coastal region of Keelung, Taiwan, was diluted 10 -fold with sterile $\mathrm{NaCl} /$ Tris buffer $\left[30 \mathrm{~g} \mathrm{NaCl}, 0.24 \mathrm{~g}\right.$ Tris (l deionized water) ${ }^{-1}$; $\mathrm{pH}$ 8.0]. Aliquots $(0.1 \mathrm{ml})$ of the 10 -fold dilutions $\left(10^{-1}\right.$ to $10^{-3}$ ) were spread on polypeptone/yeast extract (PY) plate medium (Shieh et al., 2000) in triplicate. The plates were incubated at $25{ }^{\circ} \mathrm{C}$ in the dark for 7 days under aerobic conditions. An apparently agarolytic strain, $\mathrm{SAl}^{\mathrm{T}}$, was isolated from one of the plates and was subsequently purified by successive streaking on PY plates. Maintenance of this strain in our laboratory was performed repeatedly at an interval of 3-4 months by inoculating early stationaryphase cultures grown in PY broth into 7/10-strength seawater at a ratio of 2:50 (v/v). Maintenance cultures were kept at $20{ }^{\circ} \mathrm{C}$ under aerobic conditions. The isolate has also been deposited in both the Japan Collection of 
Micro-organisms (JCM) and the Bioresource Collection and Research Center (BCRC) as lyophilized cultures.

Growth and other phenotypic properties used for physiological and morphological characterization of strain $\mathrm{SA}^{\mathrm{T}}$ were determined following established procedures described previously (Jean et al., 2006a), with modifications and additional tests as described below. Haemolysis was tested as described by Chiu et al. (2007). Hydrolysis of chitin and cellulose was tested by growth of strain $S A 1^{\mathrm{T}}$ on modified PY plate media containing either colloidal chitin (Hobel et al., 2005) or cellulose, both at $2 \mathrm{~g} \mathrm{l}^{-1}$. Congo red was added $\left(0.2 \mathrm{~g} \mathrm{l}^{-1}\right)$ to the cellulose-containing plate medium to enhance the detection of bacterial colonies that were able to hydrolyse cellulose (Hendricks et al., 1995). Positive reactions for hydrolysis of chitin and cellulose were indicated by the appearance of clear zones around the colonies on the plates. All of the test cultures were incubated aerobically at $30{ }^{\circ} \mathrm{C}$ in the dark for 7 days unless stated otherwise.

Cells grown in PY broth at $30{ }^{\circ} \mathrm{C}$ for 4 days were harvested by centrifugation. Polar lipids in the cells were extracted, purified and analysed by using the methods described by Lin \& Shieh (2006). Isoprenoid quinones in the cells were extracted, purified and analysed according to Nishijima et al. (1997), by using an HPLC apparatus equipped with a reversed-phase column $\left(4.6 \times 250 \mathrm{~mm}\right.$; Waters model $5 \mathrm{C}_{18^{-}}$ AR-II). A mixture of methanol/isopropyl-alcohol $(7: 3, \mathrm{v} / \mathrm{v})$ was used as the mobile phase, and quinones were detected at $270 \mathrm{~nm}$. Fatty acids in the whole cells grown on PY plate medium at $30{ }^{\circ} \mathrm{C}$ for 4 days were extracted, saponified and esterified, followed by GC analysis of the fatty acid methyl esters according to the instructions of the MIDI system (Sasser, 1997). This work, together with DNA G + C content determination by HPLC analysis (Shieh \& Liu, 1996), was performed by the BCRC, Food Industry Research and Development Institute, Taiwan.

Cells grown in PY broth at $30{ }^{\circ} \mathrm{C}$ for 3 days were harvested by centrifugation. Extraction and purification of total genomic DNA from the cells and PCR amplification of the $16 \mathrm{~S}$ rRNA gene were performed according to the methods described previously (Jean et al., 2006a). Sequencing of the $16 \mathrm{~S}$ rRNA gene, alignment and comparison of the resulting sequence with reference sequences available in GenBank, calculation of distance matrices for the aligned sequences and reconstruction of phylogenetic trees based on the neighbour-joining, maximum-parsimony and maximumlikelihood methods were performed as described by Shieh et al. (2004) and Jean et al. (2006a). The stability of clusters was evaluated by a bootstrap analysis of 1000 resamplings.

The nearly complete $16 \mathrm{~S}$ rRNA gene sequence (1431 nt) of strain $\mathrm{SAl}^{\mathrm{T}}$ was determined. Preliminary 16S rRNA gene sequence comparisons with those in GenBank indicated that strain $\mathrm{SAl}^{\mathrm{T}}$ belonged to the class Gammaproteobacteria. This new isolate showed no apparent relationship with other bacteria on the basis of $16 \mathrm{~S}$ rRNA gene sequence similarity. It showed $\leqslant 93 \% 16$ S rRNA gene sequence similarity to strains of any recognized bacterial species. Strain $\mathrm{SAl}^{\mathrm{T}}$ showed highest levels of $16 \mathrm{~S}$ rRNA gene sequence similarity to the type strains of Teredinibacter turnerae (92.9\%), Cellvibrio japonicus (92.9\%), Cellvibrio mixtus (92.4\%), Cellvibrio fulvus (92.1\%), Pseudomonas flavescens (91.7\%), Pseudomonas pachastrellae (91.5\%), Saccharophagus degradans (91.5\%), Microbulbifer salipaludis (91.5\%), Pseudomonas argentinensis (91.4\%), Pseudomonas elongata (91.3\%), 'Microbulbifer arenaceous' (91.3\%), Microbulbifer hydrolyticus $(91.0 \%)$, Pseudomonas pseudoalcaligenes (90.8\%) and Marinobacter excellens (90.8\%). The distant relationship between strain $\mathrm{SAl}^{\mathrm{T}}$ and these bacteria was also evident in the neighbour-joining tree; strain $\mathrm{SAl}^{\mathrm{T}}$ may represent a novel lineage in the tree, in which this isolate was an outgroup with respect to a clade that contained the type strains of T. turnerae and S. degradans (Fig. 1). A similarly distant relationship was also found in the maximumparsimony tree (not shown). However, in the maximumlikelihood tree (see Supplementary Fig. S1, available in IJSEM Online), strain $\mathrm{SAl}^{\mathrm{T}}$ formed a clade only with the type strain of $T$. turnerae, being located next to a sister clade comprising the type strain of $S$. degradans as well as species of the genus Cellvibrio. The low levels of 16S rRNA gene sequence similarity to all recognized bacterial species $(<93 \%)$, together with the phylogenetic data from the three treemaking algorithms employed, suggested that strain $S A 1^{T}$ may represent a novel species and genus.

Strain $\mathrm{SAl}^{\mathrm{T}}$ had a DNA G + C content of $55.6 \mathrm{~mol} \%$, a value greater than that for T. turnerae (49.0-51.0 mol\%) and S. degradans $2-40^{\mathrm{T}}(45.8 \mathrm{~mol} \%)$. The major fatty acids of strain SA1 ${ }^{\mathrm{T}}$ were summed feature $3(28.6 \%$ of the total fatty acids; $\mathrm{C}_{16: 1} \omega 7 c$ and/or iso- $\mathrm{C}_{15: 0} 2-\mathrm{OH}$; the two fatty acids could not be differentiated in the MIDI system), $\mathrm{C}_{17: 1} \omega 8 c(22.8 \%), \mathrm{C}_{16: 0}(14.5 \%), \mathrm{C}_{18: 1} \omega 7 c(11.0 \%)$ and $\mathrm{C}_{17: 0}(6.4 \%)$. Other fatty acids present at levels $\geqslant 1 \%$ included $\mathrm{C}_{14: 0}(3.6 \%), \mathrm{C}_{10: 0} 3-\mathrm{OH}(1.4 \%), \mathrm{C}_{12: 1} 3-\mathrm{OH}$ $(1.2 \%), \mathrm{C}_{18: 0}(1.0 \%)$ and $\mathrm{C}_{15: 1} \omega 8 c(1.0 \%)$. The major fatty acids of $S$. degradans $2-40^{\mathrm{T}}$ contained iso- $\mathrm{C}_{16: 0}$ $(37.0 \%), \mathrm{C}_{14: 0}(15.0 \%), \mathrm{C}_{10: 0} 3-\mathrm{OH}(11.0 \%), \mathrm{C}_{12: 1} 3-$ $\mathrm{OH}(6.0 \%)$ and $\mathrm{C}_{10: 0}(5.0 \%)$ (Ekborg et al., 2005; González \& Weiner, 2000), whereas only low levels of these fatty acids $(<1.0-3.6 \%)$ were detected in strain $S A 1^{\mathrm{T}}$. The fatty acid composition of $T$. turnerae has not been described. Strain $\mathrm{SAl}^{\mathrm{T}}$ contained Q-10 $(87.5 \%)$ as the predominant isoprenoid quinone. MK-9 (6.6\%) and MK$7(5.9 \%)$ were present as minor components. The polar lipids of strain $\mathrm{SAl}^{\mathrm{T}}$ consisted of phosphatidylethanolamine $(71.8 \%)$, diphosphatidylglycerol $(12.7 \%)$, phosphatidylglycerol (12.2\%) and phosphatidylserine (3.3\%). The polar lipid and isoprenoid quinone profiles of $S$. degradans and $T$. turnerae have not been reported.

Strain $S A 1^{\mathrm{T}}$ was mesophilic, halophilic and Gram-negative. It produced circular, convex and non-luminescent colonies surrounded by depressions when grown on marine agar (Difco 2216) and PY plate medium for 3-7 days. Colonies on marine agar and PY plate medium were cream-coloured and off-white, respectively. Clear yellow haloes formed 


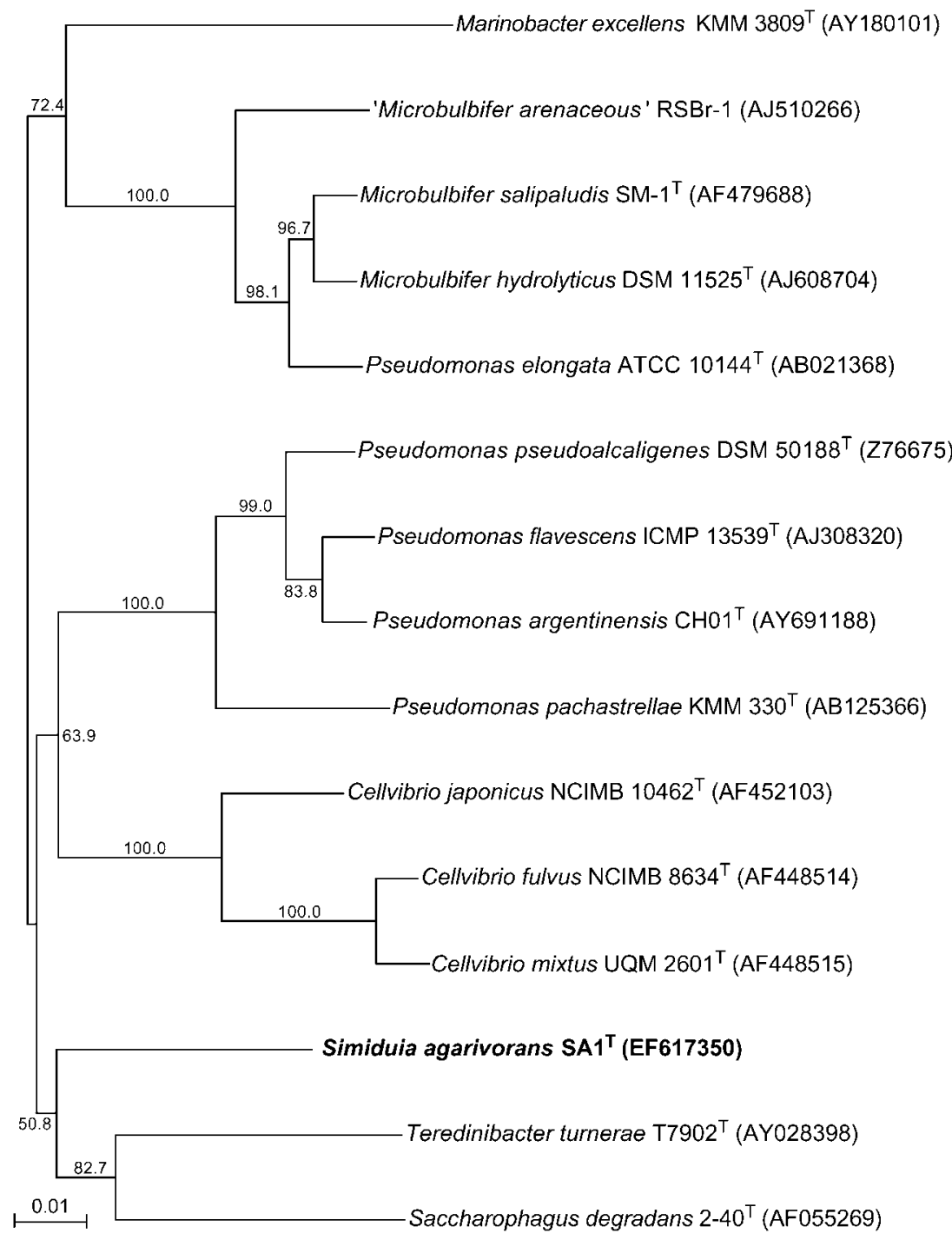

Fig. 1. Neighbour-joining tree showing the phylogenetic relationship between strain $\mathrm{SA}^{\top}$ and related bacteria in the class Gammaproteobacteria. GenBank accession numbers are given in parentheses. Bootstrap values (percentages of 1000 replicates) $>50 \%$ are shown at branch points. Bar, one nucleotide substitution per $100 \mathrm{nt}$.

around the colonies, in contrast to the purple-brown background when the agar plates were flooded with iodine/ potassium iodide solution. This indicated diffusion of agarase out from the colonies and release of reducing compounds during agar hydrolysis. Strain $\mathrm{SAl}^{\mathrm{T}}$ hydrolysed agar more rapidly on marine agar than on PY plate medium. The ability to hydrolyse agar was also reported for S. degradans (Ekborg et al., 2005), but not for $T$. turnerae. Various other bacterial species belonging to the phyla Bacteroidetes (previously known as CytophagaFlavobacterium-Bacteroides) (Yoon et al., 2007), Proteobacteria (Jean et al., 2006b) and 'Verrucomicrobia' (Scheuermayer et al., 2006; Shieh \& Jean, 1998) are also reported to be agarolytic. Cells of strain $\mathrm{SA}^{\mathrm{T}}$ were predominantly straight to slightly curved rods, approximately $2-5 \mu \mathrm{m}$ long and $0.4-0.6 \mu \mathrm{m}$ wide, during the exponential phase of growth in PY broth (Fig. 2a). Nearly all of the cells were non-motile and non-flagellated, although a few $(<1 \%)$ were motile and could be considered to have monotrichous flagella (Fig. 2b). Most of the cells formed sticky, amorphous aggregations during the stationary growth phase. Cells in the stationary growth phase had a pleomorphic morphology, often appearing as irregular, long rods 5-50 $\mu \mathrm{m}$ in length (Fig. 2c). Blebs and prosthecae were commonly produced in both the exponential and the stationary phases of growth; numerous prosthecae were produced peritrichously on the cells, and these could be branched (Fig. 2c) or network-shaped (Fig. 2a).

Physiologically, strain $\mathrm{SAl}^{\mathrm{T}}$ was distinguishable from $S$. degradans and T. turnerae in that it grew at $40{ }^{\circ} \mathrm{C}$, and not at $\mathrm{pH}$ 6. Other characteristics useful for distinguishing strain $\mathrm{SA} 1^{\mathrm{T}}$ from $S$. degradans and T. turnerae are listed in Table 1.

The data presented herein thus suggest that strain $\mathrm{SAl}^{\mathrm{T}}$ represents a novel species and genus, for which the name Simiduia agarivorans gen. nov., sp. nov. is proposed. 

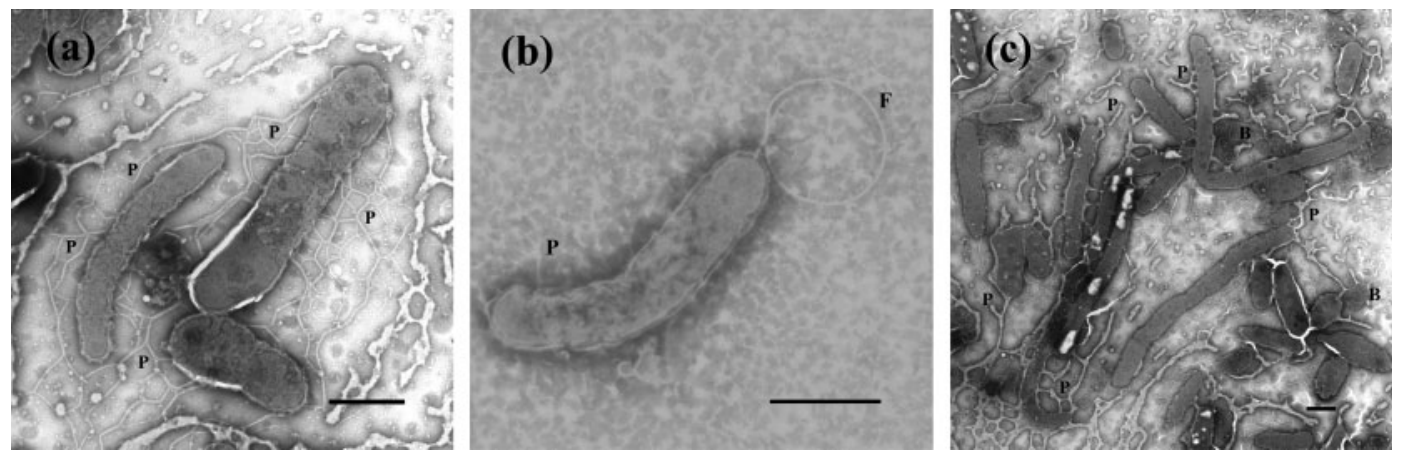

Fig. 2. Electron micrographs of negatively stained preparations of cells of strain $S A 1^{\top}$, showing blebs $(B)$, prosthecae $(P)$ and flagella (F). Cells used for analysis were grown in PY broth at $30{ }^{\circ} \mathrm{C}$ and harvested during either the exponential (a,b) or stationary (c) phase of growth. Bars, $1 \mu \mathrm{m}$.

\section{Description of Simiduia gen. nov.}

Simiduia (Si.mi'du.ia. N.L. fem. n. Simiduia named after Usio Simidu, a Japanese microbiologist, to honour his work in marine microbiology).

Cells are Gram-negative rods. Chemo-organotrophic; capable of respiratory, but not fermentative, metabolism. Mesophilic and halophilic. Oxidase- and catalase-positive. The major isoprenoid quinone is Q-10. The major polar lipid is phosphatidylethanolamine. Predominant fatty acids include summed feature $3\left(\mathrm{C}_{16: 1} \omega 7 c\right.$ and/or iso- $\mathrm{C}_{15: 0} 2$ $\mathrm{OH}), \mathrm{C}_{17: 1} \omega 8 c, \mathrm{C}_{16: 0}$ and $\mathrm{C}_{18: 1} \omega 7 c$. Phylogenetically, the genus is affiliated to the class Gammaproteobacteria. The type species is Simiduia agarivorans.

\section{Description of Simiduia agarivorans sp. nov.}

Simiduia agarivorans (a.ga.ri.vo'rans. N.L. n. agarum agar; L. part. adj. vorans devouring, destroying; N.L. part. adj. agarivorans agar-devouring).

Has the following characteristics in addition to those given for the genus. Cells are predominantly straight to slightly curved rods, approximately $2-5 \mu \mathrm{m}$ long and $0.4-0.6 \mu \mathrm{m}$ wide, during the exponential phase of growth in broth cultures. Nearly all cells are non-motile and non-flagellated; a few cells $(<1 \%)$ exhibit motility and monotrichous flagella. Most of the cells form sticky, amorphous aggregations during the stationary phase of growth. Cells in the stationary growth phase are pleomorphic, often irregular, long rods $5-50 \mu \mathrm{m}$ in length. Blebs and prosthecae are produced; prosthecae are peritrichous and can be branched or network-shaped (Fig. 2a, c). Capable of anaerobic growth by reducing nitrate as the terminal electron acceptor, but not by fermenting glucose or other carbohydrates as substrates. Colonies produced on marine agar and PY plate medium are circular, off-white to creamcoloured, convex, non-luminescent and agarolytic; marine agar is hydrolysed more readily than PY plate medium. Growth occurs between 15 and $40{ }^{\circ} \mathrm{C}$, with optimum growth at $30-35{ }^{\circ} \mathrm{C}$; no growth occurs at $4-10$ or $45{ }^{\circ} \mathrm{C}$.
Growth occurs at $\mathrm{NaCl}$ concentrations of $0.5-7 \%(\mathrm{w} / \mathrm{v})$, with optimum growth at $2-3 \%(\mathrm{w} / \mathrm{v})$; no growth occurs without $\mathrm{NaCl}$ or in the presence of $8-10 \%(\mathrm{w} / \mathrm{v}) \mathrm{NaCl}$. Able to grow over a $\mathrm{pH}$ range of 7-10, but not at $\mathrm{pH} 6$. Nitrate is reduced to nitrite, but not further to $\mathrm{N}_{2} \mathrm{O}$ or $\mathrm{N}_{2}$. Poly- $\beta$-hydroxybutyrate is not accumulated as an intracellular product. Not haemolytic. Indole is not produced from tryptophan. Aesculin, alginate, casein, cellulose, chitin, gelatin and starch are hydrolysed, but DNA, lecithin, Tween 80 and urea are not. Arginine dihydrolase, lysine decarboxylase and ornithine decarboxylase are absent. The following constitutive enzyme activities are detected in API ZYM tests: cystine arylamidase, leucine arylamidase, valine arylamidase, esterase (C4), esterase lipase (C8), $N$-acetyl- $\beta$ glucosaminidase, naphthol-AS-BI-phosphohydrolase, acid phosphatase, alkaline phosphatase and trypsin. Able to grow on the following compounds as sole carbon and energy sources: cellobiose, D-glucose, maltose, sucrose, acetate, $\beta$-hydroxybutyrate, L-alanine, L-arginine, L-glutamic acid, L-lysine and tyrosine. Unable to grow on the following compounds as sole carbon and energy sources: Darabinose, L-arabinose, cellulose, D-fructose, D-galactose, D-lactose, D-mannose, melezitose, melibiose, raffinose, ribose, trehalose, D-xylose, salicin, dulcitol, inositol, Dmannitol, citrate, fumarate, lactate, malic acid, malonate, L-aspartic acid, citruline, L-glutamine, L-glycine, L-histidine, L-isoleucine, L-leucine, L-ornithine, L-phenylalanine, Lserine, L-threonine, L-tryptophan and L-valine. Isoprenoid quinones comprise Q-10 (87.5\%), MK-9 (6.6\%) and MK-7 $(5.9 \%)$. Polar lipids comprise phosphatidylethanolamine (71.8\%), diphosphatidylglycerol (12.7\%), phosphatidylglycerol $(12.2 \%)$ and phosphatidylserine (3.3\%). Cellular fatty acids present at levels $\geqslant 1 \%$ are summed feature $3\left(\mathrm{C}_{16: 1} \omega 7 \mathrm{c}\right.$ and/or iso- $\left.\mathrm{C}_{15: 0} 2-\mathrm{OH} ; 28.6 \%\right), \mathrm{C}_{17: 1} \omega 8 c(22.8 \%), \mathrm{C}_{16: 0}$ (14.5\%), $\mathrm{C}_{18: 1} \omega 7 c(11.0 \%), \mathrm{C}_{17: 0}(6.4 \%), \mathrm{C}_{14: 0}(3.6 \%)$, $\mathrm{C}_{10: 0} 3-\mathrm{OH}(1.4 \%), \mathrm{C}_{12: 1} 3-\mathrm{OH}(1.2 \%), \mathrm{C}_{18: 0}(1.0 \%)$ and $\mathrm{C}_{15: 1} \omega 8 c(1.0 \%)$. Susceptible to ampicillin $(10 \mu \mathrm{g})$, carbenicillin $(100 \mu \mathrm{g})$, chloramphenicol $(30 \mu \mathrm{g})$, nalidixic acid $(30 \mu \mathrm{g})$, novobiocin $(30 \mu \mathrm{g})$, penicillin $\mathrm{G}(10 \mathrm{U})$ and tetracycline $(30 \mu \mathrm{g})$; intermediately susceptible to kanamycin 
Table 1. Differential characteristics between strain $S A 1^{\top}$, Saccharophagus degradans and Teredinibacter turnerae

Taxa: 1, strain $\mathrm{SAl}^{\mathrm{T}}$ (data from the present study); 2, S. degradans $2-40^{\mathrm{T}}$ (Ekborg et al., 2005); 3, T. turnerae $\mathrm{T}_{7902^{\mathrm{T}}}$ (Distel et al., 2002). +, Positive; -, negative; tr, trace amount detected $(<1 \%)$; ND, no data available. All three taxa are non-fermentative, Gram-negative bacteria that require $\mathrm{NaCl}$ for growth, grow at $20-30{ }^{\circ} \mathrm{C}$ and $\mathrm{pH} 7-10$, and are positive for oxidase and catalase.

\begin{tabular}{|c|c|c|c|}
\hline Characteristic & 1 & 2 & 3 \\
\hline Colony colour & Off-white to cream & Cream & Yellow \\
\hline Motility/monotrichous flagella & $-{ }^{*}$ & + & + \\
\hline Blebs/prosthecae & + & + & - \\
\hline Growth on Difco marine agar & + & + & - \\
\hline \multicolumn{4}{|l|}{ Growth at/in: } \\
\hline $5-7 \% \mathrm{NaCl}$ & + & + & - \\
\hline $8-10 \% \mathrm{NaCl}$ & - & + & - \\
\hline pH 6 & - & + & + \\
\hline $4-10{ }^{\circ} \mathrm{C}$ & - & + & - \\
\hline $15{ }^{\circ} \mathrm{C}$ & + & + & - \\
\hline $40{ }^{\circ} \mathrm{C}$ & + & - & - \\
\hline \multicolumn{4}{|l|}{ Hydrolysis of: } \\
\hline Agar & + & + & - \\
\hline Gelatin & + & - & $\mathrm{ND}$ \\
\hline Tween 80 & - & + & $\mathrm{ND}$ \\
\hline \multicolumn{4}{|l|}{ Utilization of: } \\
\hline Cellulose & - & $+\dagger$ & + \\
\hline D-Fructose & - & $\mathrm{ND}$ & + \\
\hline Maltose & + & $\mathrm{ND}$ & - \\
\hline D-Xylose & - & $\mathrm{ND}$ & + \\
\hline DNA G $+C$ content $(\mathrm{mol} \%)$ & 55.6 & 45.8 & $49-51$ \\
\hline \multicolumn{4}{|l|}{ Fatty acids (\% of total) } \\
\hline $\mathrm{C}_{10: 0}$ & $\operatorname{tr}$ & $5 \ddagger$ & $\mathrm{ND}$ \\
\hline $\mathrm{C}_{14: 0}$ & 3.6 & $15 \ddagger$ & ND \\
\hline $\mathrm{C}_{16: 0}$ & 14.5 & $\mathrm{ND}$ & ND \\
\hline $\mathrm{C}_{17: 0}$ & 6.4 & $\mathrm{ND}$ & ND \\
\hline $\mathrm{C}_{10: 0} 3-\mathrm{OH}$ & 1.4 & $11 \ddagger$ & ND \\
\hline $\mathrm{C}_{12: 1} 3-\mathrm{OH}$ & 1.2 & $6 \ddagger$ & ND \\
\hline Iso- $\mathrm{C}_{16: 0}$ & $\operatorname{tr}$ & $37 \ddagger$ & $\mathrm{ND}$ \\
\hline $\mathrm{C}_{16: 1} \omega 7 c$ and/or iso- $\mathrm{C}_{15: 0} 2-\mathrm{OH}$ & 28.6 & $\mathrm{ND}$ & $\mathrm{ND}$ \\
\hline $\mathrm{C}_{17: 1} \omega 8 c$ & 22.8 & ND & ND \\
\hline $\mathrm{C}_{18: 1} \omega 7 c$ & 11.0 & ND & $\mathrm{ND}$ \\
\hline
\end{tabular}

${ }^{\star}$ Cells were rarely positive.

$†$ Negative as described by Gonzàlez \& Weiner (2000).

¥Data from Gonzàlez \& Weiner (2000).

$(30 \mu \mathrm{g})$. Resistant to cephalothin $(30 \mu \mathrm{g})$, clindamycin $(2 \mu \mathrm{g})$, colistin $(10 \mu \mathrm{g})$, erythromycin $(15 \mu \mathrm{g})$, gentamicin $(10 \mu \mathrm{g})$, lincomycin $(2 \mu \mathrm{g})$, neomycin $(30 \mu \mathrm{g})$, oxacillin $(1 \mu \mathrm{g})$, polymyxin $\mathrm{B}(300 \mathrm{U})$, streptomycin $(10 \mu \mathrm{g})$ and vancomycin $(30 \mu \mathrm{g})$. The DNA G $+\mathrm{C}$ content is $55.6 \mathrm{~mol} \%$.

The type strain, $\mathrm{SAl}^{\mathrm{T}}\left(=\mathrm{BCRC} 17597^{\mathrm{T}}=\mathrm{JCM} 13881^{\mathrm{T}}\right)$, was isolated from shallow coastal water from Keelung, Taiwan.

\section{Acknowledgements}

This study was supported by grants NSC94-2313-B-002-066, NSC952621-B-002-010 and NSC94-2211-E-426-001 from the National Science Council, Taiwan.

\section{References}

Chiu, H.-H., Shieh, W. Y., Lin, S. Y., Tseng, C.-M., Chiang, P.-W. \& Wagner-Döbler, I. (2007). Alteromonas tagae sp. nov. and Alteromonas simiduii sp. nov., mercury-resistant bacteria isolated from a Taiwanese estuary. Int J Syst Evol Microbiol 57, 1209-1216.

Distel, D. L., Morrill, W., Maclaren-Toussaint, N., Franks, D. \& Waterbury, J. (2002). Teredinibacter turnerae gen. nov., sp. nov., a dinitrogen-fixing, cellulolytic, endosymbiotic $\gamma$-proteobacterium isolated from the gills of wood-boring molluscs (Bivalvia: Teredinidae). Int J Syst Evol Microbiol 52, 2261-2269.

Ekborg, N. A., Gonzalez, J. M., Howard, M. B., Taylor, L. E., Hutcheson, S. W. \& Weiner, R. M. (2005). Saccharophagus degradans 
gen. nov., sp. nov., a versatile marine degrader of complex polysaccharides. Int J Syst Evol Microbiol 55, 1545-1549.

Gonzàlez, J. M. \& Weiner, R. M. (2000). Phylogenetic characterization of marine bacterium strain 2-40, a degrader of complex polysaccharides. Int J Syst Evol Microbiol 50, 831-834.

Hendricks, C. W., Doyle, J. D. \& Hugley, B. (1995). A new solid medium for enumerating cellulose-utilizing bacteria in soil. Appl Environ Microbiol 61, 2016-2019.

Hobel, C. F. V., Marteinsson, V. T., Hreggvidsson, G. O. \& Kristjansson, J. K. (2005). Investigation of the microbial ecology of intertidal hot springs by using diversity analysis of $16 \mathrm{~S}$ rRNA and chitinase genes. Appl Environ Microbiol 71, 2771-2776.

Jean, W. D., Shieh, W. Y. \& Chiu, H.-H. (2006a). Pseudidiomarina taiwanensis gen. nov., sp. nov., a marine bacterium isolated from shallow coastal water of An-Ping Harbour, Taiwan, and emended description of the family Idiomarinaceae. Int J Syst Evol Microbiol 56, 899-905.

Jean, W. D., Shieh, W. Y. \& Liu, T. Y. (2006b). Thalassomonas agarivorans sp. nov., a marine agarolytic bacterium isolated from shallow coastal water of An-Ping Harbour, Taiwan, and emended description of the genus Thalassomonas. Int J Syst Evol Microbiol 56, 1245-1250.

Lin, Y.-T. \& Shieh, W. Y. (2006). Zobellella denitrificans gen. nov., sp. nov. and Zobellella taiwanensis sp. nov., two denitrifying bacteria capable of fermentative metabolism. Int J Syst Evol Microbiol 56, 1209-1215.
Nishijima, M., Sakai, M. \& Sano, H. (1997). Identification of isoprenoid quinones by frit-FAB liquid chromatography-mass spectrometry for the chemotaxonomy of microorganisms. J Microbiol Methods 28, 113-122.

Sasser, M. (1997). Identification of Bacteria by Gas Chromatography of Cellular Fatty Acids, MIDI Technical Note 101. Newark, DE: MIDI Inc.

Scheuermayer, M., Gulder, T. A., Bringmann, G. \& Hentschel, U. (2006). Rubritalea marina gen. nov., sp. nov., a marine representative of the phylum 'Verrucomicrobia', isolated from a sponge (Porifera). Int J Syst Evol Microbiol 56, 2119-2124.

Shieh, W. Y. \& Jean, W. D. (1998). Alterococcus agarolyticus gen. nov., sp. nov., a halophilic thermophilic bacterium capable of agar degradation. Can J Microbiol 44, 637-645.

Shieh, W. Y. \& Liu, C. M. (1996). Denitrification by a novel halophilic fermentative bacterium. Can J Microbiol 42, 507-514.

Shieh, W. Y., Chen, A.-L. \& Chiu, H.-H. (2000). Vibrio aerogenes sp. nov., a facultatively anaerobic, marine bacterium that ferments glucose with gas production. Int J Syst Evol Microbiol 50, 321-329.

Shieh, W. Y., Lin, Y.-T. \& Jean, W. D. (2004). Pseudovibrio denitrificans gen. nov., sp. nov., a marine, facultatively anaerobic, fermentative bacterium capable of denitrification. Int J Syst Evol Microbiol 54, 2307-2312.

Yoon, J., Ishikawa, S., Kasai, H. \& Yokota, A. (2007). Persicitalea jodogahamensis gen. nov., sp. nov., a marine bacterium of the family 'Flexibacteraceae', isolated from seawater in Japan. Int J Syst Evol Microbiol 57, 1014-1017. 